

\title{
Science, society and science centres
}

\section{Ciência, sociedade e centros de ciência}

\author{
Ann Mintz \\ President of the Chester County Historical Society \\ 324 West Barnard Street \\ West Chester PA 19382 USA \\ annmintz@mindspring.com
}

MINTZ, A.: Science, society and science centres.

História, Ciências, Saúde - Manguinhos, v. 12 (supplement), p. 267-80, 2005.

The present article analyzes the relation between technological changes and the advance of science, as well as the attitude of individuals in relation to science nowadays. According to researches carried out by the National Science Foundation in the United States, a large number of Americans and Europeans accept the benefits of science and technology, but have complex attitudes in relation to this topic. Contemporary cultures display this contradiction in many different ways. An evidence of this ambiguity is the prevailing image of scientists in popular culture: that of the mad scientist. Interpreting science and technology to a large and diversified audience is the main mission for most science centres. The changes that take place in society demand new approaches in the relationship with visitors. The present article analyzes the economic and intellectual sustainability of science centres and the continuously reinvented ways through which each one of them tries to shape its relationship with the community and with its identity as a science centre in the twenty-first century.

KEYWORDS: Science and Technology, society and science, science centres.

MINTZ, A.: Ciência, sociedade e centros de ciência.

História, Ciências, Saúde - Manguinhos, v. 12 (suplemento), p. 267-80, 2005.

$O$ artigo trata da relação entre mudanças tecnológicas e avanço da ciência e analisa as atitudes dos cidadãos atuai em relação à ciência. De acordo com pesquisas realizadas pela Fundação Nacional de Ciências dos Estados Unidos, boa parte da população americana e européia aprecia os benefícios da ciência e da tecnologia, mas adota atitudes complexas diante do tema, fato que a cultura contemporânea evidencia de várias formas. Prova dessa ambivalência é a imagem do cientista predominante na cultura popular: a do cientista maluco. Interpretar ciência e tecnologia para um público amplo e diverso é a principal missão da maioria dos centros de ciência. As mudanças ocorridas na sociedade exigem novos modelos de visitação. O presente trabalho analisa a sustentabilidade econômica e intelectual dos centros de ciência e as formas pelas quais cada um, reinventandose continuamente, pode encontrar sua maneira própria de se relacionar com a comunidade e sua identidade como centro de ciência do século 21.

PALAVRAS-CHAVE: ciência e tecnologia, sociedade e ciência, centros de ciência. 


\title{
The Context
}

\begin{abstract}
$\Lambda$ dvances in science and technology, including transportation, digital technologies, manufacturing and agriculture, have combined to create a lifestyle of unprecedented comfort and luxury for the citizens of the developed world. In the 19th century, when an Irishman immigrated to America, his family held an "American wake," in the certain knowledge they would never see him again. These distances, all but unbridgeable a century ago , can now be crossed for business meetings, family vacations or weekend getaways. International commerce has erased geographical and seasonal distinctions, creating a global marketplace in which the exotic has become commonplace. In 19th century novels, an orange was a special treat, tasted perhaps once a year at Christmas time. Fifty years ago, strawberries were available only for a few short weeks in the spring. Today, both are available year round, taken entirely for granted. The average American supermarket would reduce a 19th century monarch to catatonic shock.

Equally extraordinary developments have taken place in medical science. Fifty years ago, polio terrified entire communities: public swimming pools closed in the summer for fear of infection. Today, this threat has been erased and, in much of the world, is almost forgotten. Vaccinations and antibiotics have all but eliminated diseases that have been the scourges of humanity for most of our species' existence. One reason that the AIDS epidemic terrifies is that it is a reminder of the time when disease could not be cured, although it is no longer a death sentence for those who can afford the complex combinations of medications that to some extent, have changed it from an acute, fatal disease to a chronic, manageable condition.
\end{abstract}

\section{Public Attitudes and Opinions}

And yet, attitudes about science and technology are complex. The U.S. National Science Foundation releases a bi-annual report called Science and Engineering Indicators that includes information on public attitudes towards science and technology. This report consistently reveals that the vast majority of Americans recognizes and appreciates the benefits of science and technology. Approximately $85 \%$ of American respondents agree with statements such as "Science and technology are making our lives healthier, easier and more comfortable," and "Thanks to science and technology, there will be greater opportunities for future generations."

On the whole, Americans have more favorable attitudes about science and technology than people in other developed countries. 71\% of Europeans agreed with the first statement, and only 51\% of respondents in Japan. 72\% of Americans agree that "The benefits of scientific research outweigh any harmful results," compared to 50\% of respondents in Europe.

The fact that people express interest in science and technology does not mean that they are well informed about these topics. This is confirmed by both self-assessments and tests of subject matter knowledge. Less than 15\% of the public considers itself to be very well informed about new developments in science and technology, and 30\% defines itself as poorly informed. In general, people consider themselves to be less well-informed than they used to; between 1997 and 2001, scores fell five or more points on four out of five issues: space exploration, new medical discoveries, use of new inventions and 
technologies, and new medical discoveries. On the fifth issue, environmental pollution, scores fell four points. Between 2001 and 2003, progress was made in some areas. The percentage of Americans that could correctly define DNA increased from 45\% in 2001 to $60 \%$ in 2003, and a majority of Americans now know that antibiotics are not effective against viruses. These data confirm that the public is correct in its belief that it is not well informed about science and technology.

In addition to areas of ignorance, the study reveals ambivalence. The same people who express enthusiasm about the benefits of scientific research and the opportunities science is creating for future generations also express concerns. 51\% of Americans and $45 \%$ of Europeans believe that "we depend too much on science and not enough of faith." 38\% of Americans and 61\% of Europeans agreed that "Science makes our way of life change too fast." (Science and Technology Indicators 2004).

Consistently, opinion studies show that only about $10 \%$ of the U.S. population agree that human beings evolved without any divine oversight. Another 39 or $40 \%$ subscribe to a "theistic" process of evolution, in which human beings evolved from simpler organisms, but the process was "guided" in some form by a supreme being. As many as one-third believe that the Bible is the word of God, to be taken literally, including the creation of human beings. This is sharply divergent from scientists, 55\% of whom believe that evolution took place without divine oversight.

\section{Science and Pseudoscience}

Data about science and pseudoscience reveal that many people maintain belief in phenomena that exist outside the scientific paradigm. Although the vast majority of Americans report that they value science and technology, belief in what the National Science Foundation describes as pseudoscience is comparatively strong. A variety of phenomena fall within the definition of pseudoscience. More than $25 \%$ of the public in the United States affirmatively believes in astrology, and $18 \%$ is not sure whether they believe in it or not. $41 \%$ of the public describe astrology as scientific in nature. Between 50 and $60 \%$ of the American public believes in extrasensory perception. Between 30 and $33 \%$ of the public believes that sentient extraterrestrial beings have landed on Earth at some point in its history, and various surveys have found that between one-quarter and one-half of the population believes in some other form of pseudoscience - ghosts, haunted houses, lucky numbers, etc. Perhaps most striking, belief in most areas of pseudoscience has grown over the past decade.

\section{Science in Popular Culture}

These complex attitudes evidence themselves in contemporary culture in a variety of ways. Clear evidence for ambivalence about science and technology can be found in the fact that the most prevalent image of the scientist in popular culture is the Mad Scientist. There is the benevolent eccentric Mad Scientist, the comic ineffectual Mad Scientist, the Mad Scientist as warped, power- mad genius bent on taking over the world. There are very few heroic scientists, mad or otherwise.

To quote a 2000 study, "It is generally conceded that scientists and engineers have something of an image problem (Congressional Commission on the Advancement of 
Women and Minorities in Science, Engineering and Technology Development 2000) With the exception of forensic scientists, scientists are generally depicted in the media as unattractive, reclusive people (usually men) working in dull, unglamorous careers. This depiction has a direct impact on perception of scientists. This was established by studies carried out by George Gerbner, former Dean of the Annenberg School of Communications at the University of Pennsylvania.

He studied the perception of scientists among 1500 television watchers. This study determined that the more hours of television a person watches, the more likely that person is to think that scientists are odd and peculiar. (G. Gerbner and B. Linson: Images of Scientists in Prime Time Television: A Report for the U.S. Department of Commerce for the Cultural Indicators Project, U.S. Department of Commerce, Washington D.C. 1999)

This perception contradicts the prestige that the career of scientist enjoys. A 2002 Harris poll found that "scientist" ranked first among 17 occupations, the first time that the "doctor" was not the most prestigious occupation. "Doctor" held the second rank, "engineer" the seventh, two steps above "Member of Congress." In a survey conducted by the National Science Foundation in 2001, $80 \%$ of U.S. respondents and $71 \%$ of European respondents indicated that they would be pleased if their son or daughter decided to become a scientist. Yet, the mad scientist image persists.

\section{Science and Society}

Regardless of how scientists and engineers are portrayed in the media, it is entirely rational to be uneasy about our technologically complex and interdependent world. Much of our technological infrastructure relies on consumption of fossil fuels, which the great majority of scientists believe has caused and will continue to cause uncontrolled climate change, with massive global consequences. The present high rate of consumption of fossil fuel is unsustainable; it is difficult to adequately forecast the social and economic dislocation that will result when oil becomes increasingly scarce and expensive. Habitat destruction, species extinction, antibiotic-resistant strains of disease - the se are but a few genuinely troubling issues hat relate to science and technology.

Science has also created capabilities that challenge our ethical and legal standards. Some possible future capabilities were identified in an extraordinary document produced in the late 1980s by the now-defunct Office of Technology Assessment. This was part of the celebration of the Constitutional Bicentennial, an exploration of potential challenges to the U.S. Constitution that might be posed by advances in science and technology. Does satellite surveillance qualify as unusual search and seizure? If genetic testing reaches the level that intrinsic predisposition to crime can be reliably identified, would preemptive incarceration be cruel and unusual punishment?

Science and technology has not reached this stage as yet, but existing real-world issues in the bio-medical and agricultural arena stretch our ethical boundaries. These include cloning, stem cell research, genetic testing, and genetically engineered foods. Stem cell research, for instance, is a topic on which public opinions change significantly on an annual basis, and opinions about biotechnology in agriculture also have been mutable in both Europe and the United States.

Many internationally important issues with enormous economic consequences cannot be fully understood without understanding their scientific foundations. Examples drawn 
from the headlines include the U.S. withdrawal from the Kyoto Protocol to control global warming; an embargo on U.S. beef because of the possibility of Bovine Spongiform Encepha lopathy; conflict between the U.S. and the European Union concerning the E. U. resistance to genetically engineered foods and the consequent damage to the multibillion dollar American agriculture industry.

These topics present a broad range of implications: legal, ethical, environmental, economic, political, even religious. And of course, it is only a sample of the sciencerelated subjects drawn from the news.

\section{The Paradox of the Science Center}

This is the context in which science centers operate: a complex, increasingly interdependent world, shaped by science and technology. Like the society in which they operate, science centers face many challenges. Like any species, the first imperative for science centers is survival. A paradox resides at the heart of the science center. Science centers are educational institutions, but they compete economically in the crowded leisure time marketplace.

The fact that a situation can be stated simply does not mean that it is a simple situation, and a cascade of implications flows from this seemingly simple statement.

Because our world is profoundly shaped by science, the corollary assumption is that everyone needs to understand science. Unarguably, many science-related topics have public policy implications. A democratic form of government is predicated on the existence of well6 informed electorate, capable of participating in the decisions set before it, and the data show that the American public is not well-informed about science and technology. This creates both a challenge and an opportunity for science centers.

It is ironic indeed that in a world facing a myriad of gravely important issues, many of them grounded in science and technology, many science centers focus almost exclusively on making science fun and exciting, playgrounds for the mind. This may be a response to the cultural ambivalence about science and technology, seeking to attract visitors by entertaining them. The same action verbs appear and re-appear in science center marketing and promotion - Explore, Imagine, Discover, Build, Create, Try. Science center brochures often feature joyful children having a wonderful time. Indeed, children do have a wonderful time at science centers, and engaging children in science is a truly worthwhile goal. But children are not the only people in our society who need to understand science. And by over-emphasizing fun, we run the risk of literally losing the science in science centers.

Financial factors are another factor in this emphasis on the lighter side of science. Many science centers rely heavily on earned income, and it is easier to market entertainment, fun and excitement than global warming and species extinction. Revenues also come from contributed income, which derive from several sources. It may be motivated by philanthropy or desire to support an educational program, which could fund a program on a serious topic. However, contributed revenues can also be inspired by an economic development rationale or a marketing sponsorship, in which case a program that will attract a large audience is paramount. Fun and excitement is an easier sell than complex, potentially divisive topics. If only $10 \%$ of the population believes that evolution took place without the oversight of a supreme being, some institutions may 
avoid the topic of evolution for fear of offending potential visitors. At that point, marketing compromises mission.

At the same time that more and more science-related topics have appeared in the news, science center audiences have grown younger and younger. One institution reports that $55 \%$ of its audience is under 12 ; others, that half the family audience includes in the group at least one pre-schooler. The foundation audience in most science centers is families with children under the age of eleven.

One factor that is driving this trend towards younger audiences is that older children lead increasingly highly scheduled lives. Parents rarely send their children out to play in the neighborhood. Children participate in many structured extra-curricular activities. As a result, older children and their parents are often too busy to visit a science center. Younger children, who are not as engaged with sports and other formal activities, are more available for science center visits. Audiences drawn to hugely popular exhibits such as Grossology are unlikely to participate in a serious program on the ethical implications of stem cell research.

Time is the ultimate currency, the one truly and absolutely finite resource. People make decisions about what to do with the most precious commodity of all - their leisure time. Science centers are competing with a host of other options for that weekend day. It is not surprising that most institutions choose to portray themselves as an entertaining outing for the family rather than a place to confront some of the most complex issues our society faces.

\section{Serving Adult Audiences}

Interpreting science and technology for a broad and diverse audience is at the heart of the mission of most science centers. For a variety of reasons, most science centers have emphasized family audiences and, as noted above, the core audience in most science centers is families with children under the age of eleven. This is in part because programmatic and promotional resources are finite. The same resources invested in efforts aimed at the family audience are likely to result in more return on investment than when invested in programs for adult audiences - more attendance, more membership, more sales in the store, more revenue in the restaurant. More is done for the family audience, the expectation builds that the science center is a place for families, and the feedback loop continues.

For a variety of reasons, it is important for science centers to expand their programs to include adult audiences. The first is demographic. The population over the age of 50 is growing, it is well-educated, in the habit of utilizing cultural resources. Historically, people have tended to stop utilizing science centers when their children reach the age of twelve. They do not return until their gr andchildren reach science center age. When their grandchildren "graduate" at the age of twelve, they leave, perhaps never to return.

Other kinds of museums can attract audiences throughout their adult lives. This is a lost opportunity for science centers, with a variety of negative consequences. If the primary audience for science centers is families with young children, it creates dynamic and exciting institutions, but they are institutions whose support base has not attained its peak earning power. By the time these parents have reached peak earning power, they have had years, even decades, to form alliances with new institutions. Will they 
still feel loyalty to the science center they patronized so regularly when their children were young? Or will they have transferred their support to other organizations? How can science centers build endowments comparable to art museums and natural history museums if their visitors stay with them for only seven years, when their children are between the ages of five and twelve?

Science centers have long looked with envy at the social cachet enjoyed by art museums. This cachet may result from the fact that many art museums were founded on or benefit from art collected by the social elite of their communities. Becoming involved with an art museum can provide access to the upper strata of society in a community. There is no clear analogue to art collecting for the science center.

In this context, it is interesting to note that some science-related institutio ns include art in their exhibits. The Monterey Bay Aquarium recently incorporated art, including work by the much-collected contemporary glass artist, Dale Chihuly, in a recent exhibition. The Exploratorium has long been noted for its artist-in-residence program. Its best known artist, Ned Kahn, was just awarded a coveted MacArthur Foundation "genius" grant. The traveling exhibition Invention At Play included the work of the respected kinetic sculptor Arthur Ganson, who has a long-term installation at the MIT Museum, has been featured in Sculpture Magazine and has had solo shows at major art museums. The boundaries between art and science are becoming more permeable. Can this help science museums create the same cachet as art museums? Are there other strategies that can build support among the upper echelons of a community, so that becoming involved with the science center will provide access to the social elite? Or is this not the right solution? Should science centers focus on deepening their connections throughout their communities, rather than trying to become what some describe as "clubhouses" for the elite?

Another factor is the fast-changing nature of science itself. The shelf life of an education is short. Television news is the most frequently-cited source of information about developments in science and technology for both Americans and Europeans. $44 \%$ of Americans rank television news first; $60 \%$ of Europeans rank television news either first or second as their source of information about science and technology. Print media rank second, but, at 16\%, a distant second. However, since the 1980s, the percentage of Americans who watch television news has been declining.

A remarkable $30 \%$ of the U.S. respondents in the 2001 NSF survey indicated that they had obtained information about science and technology from a museum visit twice as many as from print media! Clearly, this creates a powerful opportunity for science centers. American adults are already turning to science centers for information about current developments in science and technology.

What remains to be seen is the best way to take advantage of this opportunity. The exhibit medium as it is presently understood by most science centers may not be the most effective way to present information about current science and technology. However, a model may be found at the Newseum in Washington D.C., an interactive museum about the news which is operated by journalists. Its paradigm is the morning newspaper, which is written and produced each and every day. The Newseum's exhibit on September 11, 2001 was on display on September 12, 2001. The Current Science and Technology Center at Boston's Museum of Science and Technology Center offers another model. It presents exhibits, live events, video, animations, digital updates, and live links to scientists 
working in the fields under discussion. The Current Science and Technology Center focuses on three areas: health and biology, earth and space science, and technology. These two models offer guidance to science centers as they explore ways to develop exhibits that change rapidly in response to fast-changing science news.

There is no dichotomy between programs for families and programs for adults. Nor is it a foregone conclusion that all programs for adults must be on current developments in science and technology, or on difficult, complex, divisive topics. Once science centers stop assuming that they are primarily * for* families, a variety of possibilities emerge, from technologicallybased performance art and theater (why not stage the play Copenhagen in a science center?) to stand-up comedy.

\section{Interactive Competition}

Twenty years ago, science centers virtually owned interactivity. Video games were in their infancy, most children's museums were small, the children's museum field had not experienced the dramatic growth of recent years, and few other interactive options existed. In the experience economy, the competitive universe has changed past recognition. Highly themed festival retailers, shopping malls and family entertainment centers offer interactive experiences. Children's museums look very much like science centers. Natural history museums, zoos and art museums now reach out to families and provide hands-on experiences. Almost half the homes in the U.S. have high bandwidth Internet connectivity, which provides the kind of high-end interactivity that once could be found only in science centers, with strong correlation between these homes and the demographics of science center visitors. Over $75 \%$ of the households in the U.S. with children have videogame consoles or Game Boys, providing dramatic, highly interactive experiences. 132-bit game consoles deliver stunningly realistic graphics and seamless interfaces.

Even theme parks, which once emphasized passive "dark rides," now incorporate handson exhibits because they have learned that hands-on increases dwell time. Disney, the ultimate theme park, earns half its revenue from its sky-high admissions charge. The other half comes from the sale of souvenirs and refreshments. This means that the more time people spend "on property," the more revenue the company realizes from their visit. So, hands-on pays.

The public can find interactivity in multiple venues, including their own living rooms. The result is that interactivity per se is no longer a defining characteristic for science centers.

\section{From Novelty to Commonplace}

Not too long ago, science centers were comparatively rare, primarily a feature of major cities. Visitors to these cities included the Franklin Institute, the Ontario Science Center and the Museum of Science and Industry on their "must see" list. In 1971, when discussions began about establishing the organization that was to become the Association of Science Technology Centers, 16 museum directors sat around the table. In 1973, 23 people attended the first ASTC meeting.

Today, hands-on science centers have proliferated to a remarkable extent. Large science centers exist in smaller cities, and more are in the planning stages. Many new and 
newlyexpanded centers have failed to meet their projected attendance goals and as a result, have experienced financial difficulties, curtailed operations and reduced staffing. Still, the "if we build it, they will come" mentality has surprisingly deep roots, and it prevails.

It is difficult to avoid the conclusion that the context has changed sufficiently that new models for attendance projection are needed. Many science centers are somewhat generic, difficult to distinguish one from another. They show the same large format films, present the same traveling exhibitions, perhaps even the same permanent exhibits. With science centers in more and more communities and more interactive options, visitors have more choices. More people live within driving distance of several science centers, children's museums, and other indoor interactive family recreational opportunities. And a tourist family that lives in a community with a science center might be less likely to visit a science center in another community, especially they have already seen the film that is featured in the IMAX Theater. The proliferation of science centers provides multiple opportunities for informal science education. It also has a net impact on the operation of science centers as a group.

\section{Speaking of Large Format Theaters}

The picture is complicated further by changes in the large format theater industry. Few major science centers lack a large format theater, which contributed to substantial increases in attendance at throughout the 1980s and 1990s. During these years, most theaters were in institutional settings, showing educational films. The great majority of these institutional theaters enjoyed exclusivity in their markets. The credibility of the institutions themselves created a strong brand identity for the theaters; exhibits, programs and educational films supported one another. Film-makers produced films for this institutional market, and the system sustained itself.

Starting in 1997, large format theaters began to be installed in commercial multiplexes, and the large format industry changed past recognition. Film-makers produced entertainmentoriented films for the new commercial theaters. Markets that once had a single large format theater now had several. Commercial theaters showed both standard Hollywood films and largeformat films. Institutional theaters, seeking new audiences, showed entertainment-oriented films as well as the traditional educational material. The result? The identity of large format theaters has eroded. Market share and attendance has not grown commensurate with the increase in the number of theaters. The increase in the number of theaters may have decreased their novelty and thus their marketability. According to the Large Format Cinema Association, "almost all large format theaters have suffered attendance decreases in the last five years." (Large Format Theater and Film Industry Backgrounder, Large Format Cinema Association 2003)

\section{New Models for Interactivity}

These three factors challenge science centers: an explosion of interactive alternatives, a proliferation of science centers, and changes in the large format film industry. The solution is not to keep building more generic science centers with yet another large format theater. A more viable answer is to seek new models that use interactivity in new ways. 
One option has been to emphasize cutting edge science and technology. This is a seductive possibility. Exciting and highly marketable, it is very difficult to deliver on a consistent basis. It is interesting to note that in 1994, two zones called Innoventions were created at Epcot Center, Walt Disney World. They were last renovated in 1999. Some of the products on display, such as the Segway Human Transporter, and a large array of Sega videogames, are commercially available. Innoventions has been described as a "trade show wrapped around a video arcade" by theme park critics. Apparently, even a corporation with resources as deep as Disney finds it difficult to sustain a facility with an emphasis on cutting edge technology.

Many genuinely exciting developments at the cutting edge of science and technology are somewhat arcane, difficult to explain to the general public. They take place on a molecular level, involve significant but subtle refinements to complex concepts, are not compatible with the hands-on medium, or require significant amounts of explanation before their importance is clear.

Often, when new technology is under development, few working models exist. A beta test model is often unreliable and could not possibly survive in a science center environment. Indeed, a beta test model is not always reliable when demonstrated.

Years ago, before CD ROM became a standard format, competition raged over the technical standards for multi- media. Major manufacturers had their own proprietary hardware they hoped would win, resulting in staggering profits. One manufacturer demonstrated its candidate at an industry luncheon, held at a major convention in New York City. Over a thousand people were invited; the company picked up the tab. With great fanfare, the equipment was unveiled, its capabilities to be demonstrated. The equipment crashed at this most inopportune moment. (This may be the stuff of technical legend but the author, as it happens, was at the luncheon.) By the time new technology is truly reliable, it is on the market. And if people can see something at Circuit City, why would they want to see it at the science center?

A disconnect exists between the reality of new technologies and public belief. Television and the movies have created very high expectations. To some extent, the public believes that the Star Trek Holodeck really exists. Exhibit the best virtual reality that is available. It will impress many people, but videogame-playing tweens will be somewhat blasé, because arcade games have remarkable VR. Many people will wonder why it isn't as good as what they saw on Star Trek or in the latest James Bond movie. And other people will come back in two weeks and ask what's new this time.

A more sustainable solution is to find a concept that is unique to each institution, one that is integrates interactivity but does not depend solely on it. Some institutions are goin $g$ beyond science and technology to the creativity that underlies all significant human endeavors. Others integrate science and technology with art, using art as an entry point to science and science as an entry point to art. Maintaining relationships with the scientific and technical community ensures intellectual sustainability, keeps staff engaged and helps create a culture of inquiry in the science center. It also keeps the science in the science center.

Another option is to integrate meaningful interactive experiences with authentic objects, creating experiences that cannot be replicated because the objects are literally unique. Only the Franklin Institute has a 350-ton Baldwin locomotive in its Railroads exhibit. The Franklin Institute's building was literally constructed around the locomotive, 
providing a permanent, real experience that no family entertainment center could possibly replicate.

Sense of place is crucially important. Architecture should reflect and relate to the site, so that when people visit an institution, they know where they are and where they have been. A photograph taken at a science center should not require a caption to recall its location.

\section{Science Centers and Education}

At their core, science centers are educational institutions. Whether it's called informal education or free choice learning, it is a powerful kind of self-paced exploration that empowers that learner. Famously, Frank Oppenheimer observed that no one can fail a museum. Fundamental changes in formal education have placed in sharp relief the fundamental differences between the learning environment created in a science center and the formal education system.

\section{Science Centers as Antidote to Formal Education System}

Too often, elementary and middle school teachers feel unprepared to teach science, and approach it cautiously or even fearfully. Worksheets, the antithesis of inquiry learning, ensure that the teacher does not lose control. Standardized tests are shifting the teaching profession away from a thoughtful community of practice to the rote delivery of information.

In academe, collaborative work between university and school district may not be valued in a culture that emphasizes research funding and publication. A science education professor will struggle with choices, if one set of choices leads to tenure and another does not.

Science centers have an important role to play in this shifting educational landscape. Political agendas and standardized testing shape curriculum, but science centers can help support positive change in the educational system. First and foremost, science centers are about firsthand experience, empowering people of all ages by providing rich learning environments. At their best, science centers try to understand the needs of learners through front-end evaluation and help them build bridges of understanding to science topics. Science centers can also create relationships: with teachers, universities, and parents.

Science centers are avocational; people choose to visit them. Ideally, science centers add value to their relationships with the people they serve. If the relationships do not meet the real needs of these people, they will go elsewhere. Science centers can be a safe haven, a neutral ground, a place where educators can come together, learn together, share ideas in an environment free from an increasingly constrained formal system. Science centers can empower learners and teachers as learning professionals. What they learn in the science center can inform classroom practice. This cannot happen if science centers are afraid to address topics such as evolution or climate change, which are overwhelmingly accepted by the scientific community even if they are controversial elsewhere. Evading the responsibility to include such topics can only compromise the intellectual integrity of the science center. 


\section{Empowering Parents}

Most parents believe that their local school districts are responsible for their children's education. They have delegated their children's education to the schools, which they support through the taxes they pay and political action such as electing politicians and school board members. And yet, by the time a student has graduated from high school, only $10 \%$ of his or her life has been spent in a classroom. In reality, parents are $100 \%$ responsible for their children's education. Schools are an important tool, but the world is far too complex to rely on a poorlyresourced classroom where a child spends only $10 \%$ of his or her time as a K-12 learner.

Science centers are community resources that empower parents as advocates for their children's learning. Through content-rich exhibitions and programs, parents and children can learn together. Science centers partner with schools and expand the learning resources for families. Through after-school programs, vacation and summer classes, parents are able to expand the experience base for their children. This enhances the educational infrastructure for the entire community.

\section{Managing Expectations}

Science centers are complicated institutions - more complicated than they might seem. The size of the organization is not commensurate with their complexity. They provide many different services to many different audiences, overlooked and overseen by many stakeholders. Using sound business practices is crucial, but they are not businesses. It takes a special kind of person to lead these organizations, to set the course, and to navigate the waters.

Even those who support these organizations do not always fully understand them. Applying models from the for-profit sector often does not work. Science centers are not simply producing $\$ 5, \$ 10$ or $\$ 20$ million dollars worth of product. It is not an inputoutput model.

Funders may expect clear-cut outcomes. It is difficult to document dramatic cognitive gain after a 90 minute science center visit-not impossible, but difficult. The kind of longitudinal study that documents long-term impact is expensive, and difficult for most institutions to carry out with in-house resources. There may be pressure to address topics that do not lend themselves to the exhibit medium, or are otherwise inappropriate for an individual institution. At some point, many institutions have been challenged by powerful stakeholders to be something they are not.

Ultimately, science centers are responsible for defining what it means to be successful. Once this has been clearly defined, it can be communicated to the community at large. The details of the definition may vary from institution to institution, but the core remains the same: science centers exist to provide rich, first-hand, in-depth, science-centered learning experiences for individuals of all ages.

\section{Taking a Stand}

One of the biggest questions of all relates to advocacy - not political advocacy, but advocacy of the large issues that face our society. Historically, museums have been neutral, taking no position on the topics they address. Rene d'Harnoncourt, former Director of 
the Museum of Modern Art in New York City, observed once that there is such thing as a neutral museum exhibit. An exhibit is the result of a myriad decisions, large and small. As the topics that science centers address have become more complex, strategies to present multiple points of view have evolved. Often, these points of view are personified. Sometimes, real people espouse these points of view; sometimes, points of view are abstracted, or actors play the roles of characters who take certain positions. In general, museums rarely advocate positions.

An exception is environmental advocacy, which is emerging in science centers and natural history museums. It is embodied in "green" architecture, presented in exhibitions such as Our Weakening Web, and strongly presented in large format films such as Blue Planet.

Science centers often cite the importance of using science to make informed personal decisions. Should science centers become advocates for using science to inform societal decisions? At the very least, should science centers become a place where people can discuss and explore these issues?

\section{In Search of Meaning}

In 2003, the Gallup organization released a book called The Next American Spirituality. It documented what George Gallup called an upsurge in interest in spirituality. According to surveys conducted by the Gallup organization, $40 \%$ of the American public report that they have had a religious or spiritual experience that has changed their life, which he calls one of the most dramatic findings they have ever uncovered. $80 \%$ of the American population report that they feel there is a connection between the spiritual realm and the state of the nation.

What does this have to do with science centers? In recent years, there has been much discussion of meaning in exhibition design. The fall, 1999 issue of Exhibitionist, for instance, was dedicated entirely to the subject of making meaning, with articles on such topics as Making Meaning: A New Paradigm For Museum Exhibitions?; Meaning Making Matters: Communication, Consequences, and Exhibition Design, and Experience, Inquiry and Meaning Making.

In this issue, Jay Rounds, Director of the graduate program in Museum Studies at the University of Missouri-St. Louis, noted that although there are many references to meaning in museum literature, the term is used to cover many concepts. Mihaly Csikszentmihalyi, the psychologist who developed the concept known as "flow," said that "The battle for the value of life is fought in the arena of meaning." Rounds himself favors "deep meaning," the opportunity to provide experiences that assist museumgoers in understanding the meaning of their lives, that help them construct personal narratives that connect the museum to themselves.

Science centers can be depersonalized environments. Spaces are often large and imposing, visitors and staff small by comparison. The model of the universe and of the Earth is mechanistic. At first glance, people play a minor role in the world depicted in a science center. Technology - the architecture itself, and the hands-on exhibits, is usually front and center.

Look closer, and people are often featured in science center text and graphics. These are scientists, engineers and citizens - people who made discoveries, created inventio 
ns, solved problems, cured diseases. Yet, they are small in scale compared to the environment in which they are placed, passive compared to the activity around them. All in all, little addresses people's need for "deep meaning" in their lives.

Science centers often define relevance very narrowly, in terms of connections to their visitors' daily lives. "Meaning," as defined here, goes beyond understanding the science of everyday life. It is truly the meaning of life, not how things work. Can science centers create environments that help visitors feel that human beings matter? That their lives have meaning? That they are connected to one another, part of the exquisitely balanced world around them, which in turn is part of a coherent universe?

\section{Sustaining Science Centers}

Explosive growth has been the norm throughout most the history of the science center field. That growth has slowed in recent years. Issues of identity and sustainability rather than growth are now of greatest concern.

Science centers seem to be unique to open societies. They embody a shift from topdown, teacher-driven learning to self-paced, learner-centered exploration, and may spontaneously arise in nations as they transition into open forms of government. People in new democracies will wait to vote for many hours while those in established democracies take the right to vote for granted. People with established science centers take them for granted, part of the educational infrastructure. Like any piece of infrastructure, they must be supported, or they can be lost.

Science centers should not be supported because they are like schools, or like theme parks, or even like the science centers of the 1970s, of 1980s. They deserve support because of what they are in their own right. Issues of economic and intellectual sustainability must be addressed. Intellectual integrity must be protected. Each science center must find its own identity, its own set of relationships with its community, its own unique strengths, its identity as a science center of the 21st century. Like all institutions, science centers must continually reinvent themselves. This dynamic, creative community of institutions has shown itself to be superbly responsive to changing circumstances throughout its history. Its core will remain the same: institutions dedicated to firsthand learning, passionately committed to their missions, always driven by this commitment to want to do more than they can afford in service to their communities.

Contributions to this article were made by: Gail Becker/Louisville Science Center, David Ellis/Museum of Science, Boston (ret.) Marion S. Ellis/former teacher; Raylene Decatur/Denver Museum of Nature and Science (former CEO); Alan Friedman/New York Hall of Science; Jeff Rudolph/ California Science Center; Charlie Walter/ Museum of History and Science; Charles Trautmann/ Sciencenter and Dennis Wint/Franklin Institute. Additional material was drawn from a paper produced by White Oak Associates Inc. New Models; New Words: 92 Ideas for Science Centers to Consider in Future Planning, with thanks to John Jacobsen 